\title{
Prevention of trans-boundary environmental impact: legal framework and challenges of implementation
}

\author{
By Theresa U. Akpoghome and Godwin U. AKPOGHOME*
}

\begin{abstract}
A. Abstract
Trans-boundary environmental impact occurs where development projects in one country or state have extra-territorial effect on neighbouring state and this aspect of environmental law falls squarely within the purview of international environmental law. This paper examines the prevention of trans-boundary environmental impact, legal framework and challenges of implementation in Nigeria and generally. The paper adopts a doctrinal approach. The paper discusses trans-boundary environmental impact and its origin in Nigeria. The paper notes that the first trans-boundary environmental impact in Nigeria happened in 1988 and prior to that there was no substantive environmental legislation in place. The paper evaluates the existing domestic and international legal frameworks and discovers that the substantive domestic law in Nigeria, lacks the necessary impetus to address environmental impact of a trans-boundary nature. The paper further finds that the international framework are not complemented by strong, substantive international law. Some of these treaties are married by vague language and weak enforcement mechanisms. The paper notes that there are several challenges preventing implementation of trans-boundary EIA and includes cost of trans-boundary EIA, limited access to document in the affected areas and unwillingness of the public to participate with an activity in another state. The paper recommends that the existing legal frameworks both at the national and international fora should be supported by strong substantive laws to enable implementation and concludes that the challenges can be overcome by specifying the parameters for determining the significance of effects, encourage public participation and dispute resolution mechanisms. Key Words: Environment, Assessment, Impact, Prevention, Challenges, Implementation
\end{abstract}

\section{Introduction}

Environmental Impact Assessment (EIA) is an established mechanism of environmental law and policy designed to ensure that human activities that will cause adverse environmental impacts are assessed before decisions to embark on such projects are made by either individuals,

* Theresa U. Akpoghome, Professor of Law, Department of Public Law, Faculty of Law, Benson Idahosa University, Benin City, Edo State, Nigeria. Ph: +2348065436545, 08056317472. E-Mail: teremajor@gmail.com, takpoghome@biu.edu.ng.

Godwin U. Akpoghome, BA, MA (International Studies and Diplomacy), PhD Candidate, University of Benin, Nigeria. Ph. +2348033193890, E-mail: uzowin2012@gmail.com. 
organizations and the government agencies responsible for such ${ }^{1}$ EIA is more often applied to projects and activities with capacity or potential to cause environmental impacts within the boundaries of a state but environmental impact of projects are not limited to the boundaries of a state. It can go beyond the boundaries of a sovereign state to affect another state and when this happens it becomes trans-boundary environmental impact. The goals of EIA includes improving the quality of information to enable decision-makers come up with better decisions from the view point of the environment. ${ }^{2}$ It also helps in raising the level of public participation in relation to environmental protection. ${ }^{3}$ Trans-boundary environmental impact falls within the scope of international environment law. In this regard, it is regulated by treaties, customary laws and protocols. States also have a role to play in ensuring that there is an effective EIA legislation within their territories in addition to international commitments they should make in this regard.

The issue of prevention has been emphasized by the expert group on environmental law of the World Commission. Article 10 recommended by the group in respect of trans-boundary natural resources and environmental interferences reads: "States shall, without prejudice to the principles laid down in articles 11 and 12, prevent or abate any trans-boundary environmental interference or a significant risk thereof which causes substantial harm-i.e. harm which is not minor or insignificant". ${ }^{4}$ It is again noted that the established principle of prevention was highlighted in the arbitral award in the Trail Smelter case ${ }^{5}$ and was re-emphasized not only in Principle 21 of the Declaration of the United Nations Conference on the Human Environment, ${ }^{6}$ and Principle 2 of the Rio Declaration, but also in General Assembly resolution 2995 (XXVII) of 15 December 1972 on cooperation between states in the field of environment. This principle is also reflected in Principle 3 of the Principles of Conduct in the field of the environment for the guidance of states in the conservation and

1 C.J. Bastmeijer and Timo Koivurova, Theory and Practices of Trans-boundary Environmental Impact Assessment, Legal Aspects of Sustainable Development, Vol. 1 (Martinus, Nijhoff Publishers, 2008) 1, https://www.brill.com/view/htle.13066 (accessed 8th September, 2021).

2 Timo Koivurova, Trans-boundary Environmental Impact Assessment in International Law, The Northern Institute for Environmental and Minority Law/University of Lapland, (Earthscan; 2011)p1.

https://www.researchgate.net/publications/26024425 (Last accessed 1th September 2021).

3 Ibid.

4 Environmental Protection and Sustainable Development: Legal Principles and Recommendations, (Graham and Trotman/Mart Nijhoff, 1987) 75; adopted by the expert group. It was also noted that the duty not to cause substantial harm could be deduced from the non-treaty-based practices of states, and from the statements made by states individually and/or collectively. See J.G. Lammers, Pollution of International Water Courses (Martinus Nijhoff, 1984) 346 - 347 and $374-376$.

5 Trail Smelter Case, 3 UN Rep. Intl Arb. Awards 1905 (1941).

6 The Stockholm Declaration - Report of the United Nations Con. on the Human Environment Stockholm, 5 - 16 June 1972, (United Nations Publication, Sales No. E. 73, 11. A. 14 and corrigendum), part one, chap 1 . 
harmonious utilization of natural resources shared by two or more states, adopted by the Governing Council of UNEP in 1978, which provides that States must:

Avoid to the maximum extent possible and... reduce to the minimum extent possible the adverse environmental effects beyond its jurisdiction of the utilization of a shared natural resource so as to protect the environment, in particular when such utilization might:

(a) Cause damage to the environment which could have repercussions on the utilization of the resource by another sharing state;

(b) Threaten the conservation of a shared renewable source;

(c) Endanger the health of the population of another state. ${ }^{7}$

Prevention of trans-boundary harm to the environment, persons, and property has been accepted as an important principle in many multi-lateral treaties concerning protection of the environment, nuclear accidents, space objects, international water course, and management of hazardous waste and prevention of marine pollution. ${ }^{8}$ The topic on prevention of trans-boundary environmental harm has assumed a great significance and quite topical. The emphasis is on the duty to prevent as against the obligation to repair, remedy or compensate.

Prevention should be the preferred policy since compensation in situations of harm or damage often cannot restore the environment to its previous state before the harm. ${ }^{9}$ The duty to prevent is a due diligence duty on States and this is important as the knowledge regarding the operation of dangerous activities, materials used and the process of managing them and the risks involve is ever growing.

Legally, the enhanced ability to trace the chain of causation i.e. the physical link between the activity and the harm, and even the several intermediate links in such a chain of causation makes it also imperative for operators of hazardous activities to take all steps necessary to prevent harm, albeit, prevention as a policy is better than cure. ${ }^{10}$ This paper considers the prevention of trans-boundary environmental impact, the legal framework and challenge of implementation. This paper pays particular attention to Nigeria but will

7 UNEP, Environmental Law: Guidelines and Principles No. 2, Shared Natural Resources (Nairobi, 1978) 2. The Principles are reproduced in ILM, Vol. 17, No 5 (September 1978) 1098. See also Decision 6/14 of 19 May1978 of the Governing Council of UNEP, Official Records of the General Assembly, Thirty-Third Session, Supplement No 25 (A/33/25), and Annex 1.

8 For a collection of treaties arranged according to the area or sector of the environment covered and protection offered against particular threats, see E. Brown Weiss, D.B Magraw and P.C. Szasz, International Environmental Law: Basic Instruments and References (Dobbs Ferry, NY; Transnational 1992). P. Sands, Principles of International Environmental Law Vol. 1: Frameworks, Standards and Implementation (Manchester University Press: 1975).

9 Draft Articles on Prevention of Trans-boundary Harm from Hazardous Activities with commentaries, United Nations, 2008, p148.

10 Ibid. 
consider other jurisdictions in order to arrive at a balanced assessment. Consequently this paper is divided into eight parts including the introduction. Part II considers conceptual definitions, Part III discusses the background of trans-boundary environmental hazard in Nigeria. Part IV discusses the legal frameworks on EIA and Trans-boundary Environmental Impact Assessment (TEIA). This includes domestic legislation(s) and international frameworks operative in Nigeria, Part V discusses the challenges of implementing EIA while part VI examine some benefits of trans-boundary EIA. Part VII makes recommendations while part VIII concludes the paper.

\section{What is Trans-boundary Environmental Impact Assessment}

Damage to the environment may often be anticipated when projects are embarked upon by individuals, organizations or States. It is believed that the impact that a project will have on the environment can be assessed at the design stage. ${ }^{11}$ However environmental impacts or threats do not respect national boundaries therefore, the impact that a project will have across national boundaries may never be known except the countries to be affected are carried along or consulted in the design process. ${ }^{12}$ Environmental impact assessment (EIA) is an important tool for an integrated approach to the protection of the environment, as it requires a comprehensive assessment of the environmental impacts of an activity. ${ }^{13}$ Trans-boundary environmental impact assessment in international law has the following elements-customary international law which prohibits trans-boundary pollution and this is contained in principle 21 of the Stockholm Declaration of $1972,{ }^{14}$ which provides that States must ensure that activities within their territory or under their control do not harm the environment beyond their territory. To ensure that activities within their jurisdiction will not cause trans-boundary harm, States must assess the potential trans-boundary effects of the activities and consequently should enter into international agreements requiring them to carryout trans-boundary environmental impact assessment (Trans-boundary EIA) for activities that might cause harm. ${ }^{15}$

Nigeria ${ }^{16}$ and some other countries have environmental impact assessment legislations. ${ }^{17}$ EIA is applied in order to identify and assess the likely environmental impacts

11 "Benefits and Cost of Trans-boundary EIA: Applying the UNECE Convention on Environment Impact Assessment in a Trans-boundary Context", http://www.unece.org/eia/pamphlets.org (accessed 20 August 2021) 1-4.

12 Ibid.

13 Ibid.

141972 Stockholm Conference Declaration, Principle 21.

15 John H. Knox, "The Myth and Reality of Trans-boundary Environmental Impact Assessment," American Journal of International Law, (2002), Vol. 96, Issue 2, 291 - 319.

16 Environmental Impact Assessment Act, Cap E12, Laws of Federation of Nigeria 2004.

17 Environmental Impact Assessment (EIA): An Introduction, 2015, Western Cape Government, Environmental Affairs Development Planning, South Africa. 
of the projects; report on those impacts and on measures to be taken to mitigate, prevent or reduce them; allow public and other stakeholder to comment on the project and the EIA report and provide the EIA report and the comments of the public and other stakeholders to the decision makers. ${ }^{18}$ The EIA process is systematic, holistic and multidisciplinary. Its major benefits is advice on improved project design that lowers the costs of impaired human health; loss of valuable natural resources, financial penalties for remediation and compensation as a result of damage to the environment and human health and safety. ${ }^{19}$ It can thus safely be said that EIA evaluates the potential impact of human activities or actions such as development proposal on the receiving environment and how the opportunities and constraints in this environment influence the intended human actions ${ }^{20}$ within the barriers of a state or extra territorially.

\section{Background of Trans-boundary Environmental Hazard in Nigeria}

Before 1988, Nigeria had no specific environmental legislation. Her response to environmental concerns were on ad hoc basis. ${ }^{21}$ The Nigerian Criminal Code ${ }^{22}$ has provisions regulating some environmental breaches such as the pollution of water sources, the burial of corpses within a hundred yards of residential home and the sale, possession and manufacture of matches with white phosphorus. ${ }^{23}$ There was no specific legislation as noted earlier regulating specific environmental hazard such as pollution by whatever means or any for hazardous waste ${ }^{24}$ or environmental impact of projects or human activities. Most of the existing environmental frameworks at that time were in direct response to problems associated with the new industrializing economy of Nigeria and the discovery and processing crude oil in commercial qualities.

The export of hazardous waste to developing countries received international attention in 1988 when, after a series of well publicized "garbage barges laden with waste sailed around the world seeking disposal site. The garage barges were rejected by both developing and industrial countries alike. ${ }^{25}$ Unfortunately, 3800 tons of toxic waste were dumped in a dirt in Koko-Nigeria between August 1987 and May 1988 consequent upon a business

18 "Benefits and Costs of Trans-boundary EIA", (n 11) 1.

19 South African "EIA" (n 17) 5.

20 Ibid, 4.

21 Ikhariale, M, "The Koko Incident, the Environment and the Law"; In Shyllon, F (ed.), The Law and the Environment in Nigeria (Ibadan, Vintage Publishers 1989) 73 - 75.

22 Section 245 -248 Nigeria Criminal Code.

23 Ibid. See also Atsegbua. L et al, Environmental Law in Nigeria: Theory and Practice (Ababa Press, 2004) 4-5.

24 Ola C.S, Town and Country Planning and Environmental Laws in Nigeria, $2^{\text {nd }}$ ed. (Ibadan University Press 1984) petroleum refining regulation 1974 the oil pipeline Act 1956, the factories Act.

25 Atsegbua (n 23) 56. Such Legislations include: The Oil in Navigable Waters Act, 1968, Oil in Navigable Waters Regulations, 1968; Petroleum Act 1969; Petroleum Drilling and Production 
deal concluded by an Italian waste trader and a Nigerian. ${ }^{26}$ In June 1988, the Nigerian government discovered the toxic waste at Koko, a remote part of southern Nigeria after recurring reports of local residents falling ill as a result of the toxic waste. ${ }^{27}$ The attendant media and public outcry prompted the Nigerian government to swing into action. ${ }^{28}$ Through diplomatic channels, Nigeria government ordered Italy to retrieve the wastes. A German freighter, the Karin B picked up part of the waste in July and attempted to find Western European countries that would accept the waste. ${ }^{29}$ After six countries refused to accept the waste, Karin $B$ returned to the Italian port of Livorno to face hostile dockworkers who refused to unload the waste for over two months. ${ }^{30}$ By the middle of 1990 , the waste were repackaged and sent to the United Kingdom for Incineration. ${ }^{31}$ In August 1998, a second vessel, the Deep Sea Carrier, loaded the rest of the waste from Koko, and faced similar rejections from States. After a year of waiting for permission to dock, the vessel finally unloaded the waste at Livorno. ${ }^{32}$

The government of Nigeria followed this action by organizing an international workshop on the environment. ${ }^{33}$ This conference gave impetus to the formulation of a national policy on the environment. ${ }^{34}$ Thereafter, the Federal Environmental Protection Agency 1988 (FEPA) was created and charged with the administration and enforcement of the environmental law. ${ }^{35}$ Added to this, the federal government enacted the Harmful Waste (Special Criminal Provision) Act 1988. The Act was specifically enacted to deal with illegal dumping of harmful waste. ${ }^{36}$ Another aspect of trans-boundary movement of waste

Regulation 1969; Petroleum Drilling AND Production (Amendment) Regulation 1973, Petroleum Refining Regulation 1974, The Oil Pipeline Act 1956, The Factories Act.

26 Sylvia F. Liu "The Koko Incident: Developing International Norms for the Trans-boundary Movement of Hazardous Waste", Journal of Natural Resources and Environmental Law (1992), Vol. 8 Issue 1, Article 9, 121 - 154, http://www.uknowlegde.uky.edu/jnrel/vol8/iss1/9, (accessed 17 August 2021).

27 Ibid.

28 Ibid.

29 Gozie, S. Ogbodo "Environmental protection in Nigeria: Two decades after the Koko Incident," Annual Survey of International \& Comparative Law (2009), Vol. 15, Issue 1, Article 2, 1 -18, http://www.digitalcommons.law.ggu.edu/ann/survey/vol15/iss1/2 (Last accessed 17 August 2021).

30 Sylvia Liu (n 26) 122.

31 Ibid.

32 Ibid.

33 "Crew Fell Sick on Toxic Waste Ship", The Times (London, September 3, 1985), 1. See also "Dirty Jobs, Sweet Profits", US News and World Report, Nov. 21, 1988 at 155. See "Waste Dumpers Turning to West Africa", NY Times, July 17, 1988, 1 at 1, Column 2.

34 The Nigerian government in collaboration with the United Nations Environment Program (UNEP) organized a workshop from September 12-16, 1988. See Atsegbua (n 23) 57.

35 Ibid.

36 Federal Environmental Protection Act 1988. This Act has been repeated by the National Environment Standards and Regulations Agency (Establishment) Act 2007. 
is the importation of Electronic (e-waste) into Nigeria. Nigeria's history with trans-boundary movement of hazardous waste has influenced its stringent legislative responses to such imports including the decision to ban the trans-boundary movement of e-waste. ${ }^{37}$ The effectiveness of the ban on e-waste remains in doubt as the country is flooded with non-functional electrical and electronic equipment (EEE) or near end of life $\mathrm{EEE}^{38}$

No one is in doubt that some African countries including Nigeria are feeling the negative impacts of the trans-boundary movement of electronic waste as Africa is emerging as a destination of choice for the dumping of e-waste. ${ }^{39}$ This trans-boundary movement is fuelled by the high level of consumption of electrical and electronic equipment (EEE) especially used and discarded equipment imported from the developed countries. ${ }^{40}$ It is observed that the imports have been vital in bridging the difference in digital access between African States and the developed countries, thereby improving the socio-economic development of the citizens in Africa. ${ }^{41}$

The increased consumption of used EEE in Africa has led to an increase in the volume of e-waste generated within the continent. The Secretariat of Basel Convention (SBC) defines E-waste as "Electrical and electronic equipment that is no longer suitable for use or that the last owner discarded". ${ }^{42}$ These wastes present significant human health and environmental challenges when they are not properly disposed due to the presence of several lethal chemicals or substances contained in the wastes, which includes heavy metals like mercury, lead, benyllium, bromine and organic compounds. ${ }^{43}$ This waste is known to be the fastest growing waste stream in the world. ${ }^{44}$

37 Emeka P Amechi and Babatunde A Oni, "Import of Electronic Waste into Nigeria: The Imperative of a Regulatory Policy Shift", Chinese Journal of Environmental Law (2019), Vol.3, 141-146 at 141.

38 Ibid.

39 Simpson J, "Africa Emerging as E-waste Dumping Ground", (Toxic Alerts, December, 2006) https://www/enews.toxicslink.org/news-view.php?id=3>(Last accessed 2 September 2021).

40 Ibid.

41 Secretariat of Basel Convention (SBC): Where are WECE in Africa? Findings from the Basel Convention E-Waste Africa Program (Dec 2011) 15 http://www/basel.int/portals/4/download.as px?d=UNEP-CHW-E-waste-PUB-WeeAfricaReport.English.pdf (Last accessed $3^{\text {rd }}$ September 2021), and Ministry of Information and Communication Technology (ICT), Electronic Waste (E-waste) Management Policy for Uganda (2012), 10, https://www.ict.gov.ug/sites/default/files/re sources/electronic\%20waste\%20management $\% 20$ policy\%20for\%20uganda.pdf (Last accessed $3^{\text {rd }}$ September 2021).

42 SBC (n 41), 7. See also the Abuja Platform on E-waste, a Communique issued by the International Conference on E-Waste Control, Abuja 20-21 July 2009.

43 Such as chlorine. Puckett and Smith, T, "Exporting Harm: the High Tech Trashing of Asia (Basel Action Network (BAN)), 2002) 4 - 10, https://www.ban.org/E-waste/techntrashfinalcomp.pdf (Last accessed 3rd September, 2021).

44 Toxics Links, E-Waste in India: System Failure Imminent-Take Action Now, (2004); https://www .toxicslink.org/docs/06040_repering.pdf (Last accessed 4 September, 2021). See also Bidwell, A "UN Seeks to Solve Growing Global E-Waste Problem," US News and World Report (16 Dec. 
The increase in e-waste in Africa has become a major concern to policy makers in the region. ${ }^{45}$ The magnitude of the problem of e-waste in Africa was recognised by the conference of the parties to the Bamako Convention ${ }^{46}$ in 2018. ${ }^{47}$ Part of the preamble to the decision on the prevention of electronic hazardous waste stated:

Aware that the amount of e-waste resulting from household consumption of electronic products is increasing rapidly in Africa and will have a negative impact on health and the environment unless measures are taken, as a matter of urgency, to equip African sub-regions and States with collection and recycling infrastructure. ${ }^{48}$

The modern recycling and disposal practices and equipment are virtually nonexistent in the informal sector as they employ rudimentary recycling and disposal practices. The same is also applicable in the formal sectors in most African countries except a few such as Kenya and South Africa. ${ }^{49}$ This has exacerbated the risks associated with e-wastes. Aside the challenges posed by toxic wastes and e-waste, industrial activities of another state that produces substances in the air, water and land sharing boundaries are also felt across borders. The pollution coming from the neighbouring State gives rise to trans-boundary environmental pollution. ${ }^{50}$ Trans-boundary responsibility is found in the rule that a State takes responsibility for its activity within its territory which causes pollution across boundaries of its neighbouring States. This rule can be traced to the Trail Smeller Arbitration in which Canada was held liable for acts within its territory that affected the United States of America. ${ }^{51}$ Trail smelter arbitration was the first and still the only adjudicative precedent

2013), htts://www/usnews.com/news/articles/2013/12/16/un-seeks-to-solve-growing-global-e -waste-problems/ (Last accessed 4 September 2021). See Department of Environmental Affairs, "Minister Molewa Leads National Consultative Conference on Electronic and Electrical Waste (E-waste management in South Africa"; Press Media Release ( $4^{\text {th }}$ September 2015$)$ https://www.e nvironment.gov.za/madiarelease/molewa-e-waste-conference/(Last accessed $4^{\text {th }}$ September 2021).

45 "East African Countries to Cooperate on e-waste management", Xinhua (25 ${ }^{\text {th }}$ August 2016), https:/ /www.kassfm.co.ke/new/index.php/business/item/1664-east-african-countries-to-coporate-on-e-wa ste-management, (Last accessed 7 September 2021).

46 Bamako Convention on Ban of the Import into Africa and the Control of Trans-boundary Movement and Management of Hazardous Waste within Africa, 30 ILM 773 (Bamako Convention); Nigeria has signed but yet to rectify the Bamako Convention.

47 Conference of the Parties to the Bamako Convention on the Ban of the Import into Africa and the Control of Trans-boundary Movement and Management of Hazardous Wastes within Africa, Second Meeting, Abidjan, Cote d' Ivoire, 30 January - 1 February 2018.

48 Decision 2/6 Prevention of electronic hazardous waste and the import and dumping of end -of-life waste electrical and electronic equipment in Africa $2018 \mathrm{UNEP} / \mathrm{BC} / \mathrm{co} / 2 / 6 /$.

49 SBC (n 41) 24 - 25. See Jin J., "E-Waste and the Regulatory Commons: A proposal for the Decentralization of International Environmental Regulation", Brooklyn Journal of International Law (2014), Vol. 39, $1251-82$ at $1256-8$.

50 Kutner, L, "The Control and Prevention of Transnational Pollution: A Case for World Habeas Ecologicus, U. Maimi Inter-Am L Review, (2015), Vol. 9, 257.

51 Arbitral Trib: 3 UN Rep. Intl Arb. Awards 1938 (1941). 
from an international tribunal that directly addressed the substantive law of transnational pollution. ${ }^{52}$

Consequently States are required to undertake due diligence to prevent significant (or substantial) trans-boundary environmental harm from activities within their jurisdiction or control. ${ }^{53}$ State responsibility is an established principle of international law that protects the rights of aliens. ${ }^{54}$ It is invoked when a State commits an international wrong against another State ${ }^{55}$ This rule has risen to the status of general principle of international law. The responsibility of States is a reflection of the limitation of external State sovereignty especially when it breaches an obligation undertaken with a treaty while causing loss or damage to another state. ${ }^{56}$ Air, water and ground water contamination can cross boundaries. ${ }^{57}$ Trans-boundary pollution is pollution whose physical origin is situated wholly or in part within the area under jurisdiction of one State and which has adverse effects, other than effects of a global nature in the area under the jurisdiction of another State. ${ }^{58}$

Addressing trans-boundary, environmental pollution requires that nations cooperate where their interest will be better served and collectively deal with common environmental threat. ${ }^{59}$ This will require both international and domestic law. ${ }^{60}$ Trans-boundary environmental pollution can cause different human and resources damage which includes but not limited to the depletion of the ozone layer, global warming, damage to human health, loss of biodiversity and reduction in agricultural productivity. ${ }^{61}$ A good example of trans-boundary impact is global warming caused by trans-boundary air pollution. Global warming is the increase in the global average temperature ${ }^{62}$ and it is caused by increase in atmospheric greenhouse gases concentration. ${ }^{63}$

Nigeria being an oil producing nation has had its fair share of pollution - air, water and underground water which may have crossed international boundaries. The next section

52 Thomas W. Merrill, “Golden Rules for Trans-boundary Pollution”, Duke Law Journal (1997), Vol. $46,931-35$.

53 Knox (n 15) 294.

54 Brownlie Ian, System of the Laws of Nations: State Responsibility Part I (Oxford University Press; 1983).9.

55 Brownlie Ian, Principle of Public International Law, $5^{\text {th }}$ ed. (Clarendon Press: 1998) $435-6$.

56 Milka Dimitrovska "The Concept of International Responsibility of State in the International Public Law System", Journal of Liberty and International Affairs (2015), Vol.1, No.2, 4.

57 Merill (n 52) 935.

58 Noah D Hall, "Trans-boundary Pollution: Harmonizing International and Domestic Law", University of Michigan Journal of Law Reform (2007), Vol. 40, No.4, 681 - 746 at 681.

59 Hakeem O. Ijaiya, "Note on: Responsibility of Transnational Environmental Pollution under International Environmental Law", Haramaya Law Review (2017), Vol. 6, 111 -124 at 113.

60 Ibid.

61 Ibid.

62 Naomi Oreskes, "The Scientific Consensus on Climate Change", SCIENCE (2004), Vol. 306, No.5702, 1686 DOI:10 1126/science.1103618.

63 Ibid. Other gases such as methane, CFCs, nitrous oxide are also responsible for global warming. 
of this paper examines the legal framework put in place to regulate and prevent the trans-boundary impact of actions on the environment.

\section{Legal Framework on Prevention of the Trans-boundary Environmental Impact in Nigeria.}

As noted earlier in this paper, Nigeria is an oil producing State and incidences of pollution as a result of that geological and geophysical activities abound. These activities may likely have trans-boundary impacts. This section x-rays the legal frameworks put in place at the international, regional and national levels to address trans-boundary effects before or after they occur. The framework at the international level is divided into two: the binding and non- binding instruments. These will be articulated and discussion will be made on them where appropriate.

Binding Instruments:

Convention on the Preservation of Marine Pollution by Dumping of Wastes and other Matter (London 1972); Convention Concerning the Protection of World Cultural and Natural Heritage (Paris 1972); International Convention for the Prevention of Pollution by Ship and Protocol thereto (London 1973); Convention on International Trade in Endangered Species of Wild Fauna and Flora (Washington 1973) (CITES 1973); Convention on the Long-Range Trans-boundary Air Pollution (Geneva 1979); United Nations Convention on the Law of the Sea (UNCLOS) (Montego Bay 1982); Protocol on Substances that Deplete the Ozone Layer (Montreal 1987); Convention on the Regulation of Antarctic Mineral Resource Activities (Wellington 1988); Convention on the Control of Trans-boundary Movement of Hazardous Wastes and their Disposal (Basel 1989); Convention on Environmental Impact Assessment in a Trans-boundary Context (Espoo 1991) (UNECE 1991).

Non-Binding Instruments:

Stockholm Conference Declaration- Principle 21 (1972);

UNEP adopted in 1978 the Draft Principles of Conduct in the Field of the Environment for the Guidance of State in the Conservation and Harmonious Utilisation of Natural Resources Shared by Two or More States (UNEP 1978);

The IUCN, UNEP, WWF, UNESCO and the FAO introduced the World Conservation Strategy in 1980 (IUCN 1980); UNEP General Council adopted the Monte-vidoe Programme (UNEP 1982) for the Development and periodic Review of Environmental Law; In 1982 the UN General Assembly adopted the World Charter for Nature (UN 1982b); The UN General Assembly in 1983 voted to establish the World Commission on Environment and Development (WCED); In 1991 the World Bank, UNEP and the UNDP established the Global Environmental Facility (GEF); the World Bank formed an environmental De- 
partment due to pressure to integrate environmental and developmental considerations into the processes and decisions regarding its loan making;

Rio Declaration- Principle 2 and Principle 7= Principle of common but differentiated Responsibility and Agenda 21 which limits the storage of radioactive waste near the sea. Agenda 21 reflects emerging rules of customary law.

Regional:

Bamako Convention on the Ban of Imports into Africa and the Control of Trans-boundary Movement and Management of Hazardous Wastes within Africa 1991.

\section{a. International Frameworks}

The principle of state responsibility for pollution that affects neighbouring states was first enumerated in the Trail Smelter case (US v Canada). ${ }^{64}$ In this arbitration the United States claimed against Canada on the grounds that the burning of Sulphur in Canada was affecting lives and livelihood in the US and wanted Canada to cease from the activity. Canada was held liable for acts within its territory that affected the United States. The arbitration gave rise to the established principle popularly known as the "no harm rule". The court recognized the rights of states to exploit the natural resources within their boundaries but held that states must be careful to ensure that their neighbours are not affected. This case was the first and remains the only case on trans-boundary environmental pollution.

We begin this discussion by examining the soft laws/ Declarations on Trans-boundary environmental impacts.

\section{Stockholm Conference 1972}

In 1972, the Stockholm conference held and this conference in its Declarations recognised the sovereign rights of each state upon its natural resources noting that it is limited by the responsibility for trans-boundary harm. The Stockholm Declaration ${ }^{65}$ posits:

States have in accordance with the Charter of the United Nations and the principles of international law, the sovereign right to exploit their own resources pursuant to their own environmental policies, and the responsibility to ensure that activities

64 Arbitral Trib. 3 UN Rep. Int'l Arb. Awards 1938 (1941).

65 Principle 21, Stockholm Declaration 1972. Prevention of trans-boundary harm rising from hazardous activities is an objective well articulated by principle 2 Rio Declaration on Environment and Development (Rio Declaration) and confirmed by the ICJ in its Advisory Opinion on the Legality of the Threat or Use of Nuclear Weapons which now forms part of international law. 
within their jurisdiction or control do not cause damage to the environment of other States or areas beyond the limits of national jurisdiction. ${ }^{66}$

Twenty years after, Stockholm Principle 21 was reaffirmed in Principle 2 of the Rio Declaration with the sole change of adding the adjective "developmental" between the words "environmental" and policies". ${ }^{67}$ Principle 2 of the 1992 Rio Declaration provides that:

States have in accordance with the Charter of the United Nations and the principles of International Law the sovereign right to exploit their own resources pursuant to their own environmental and developmental policies, and the responsibility to ensure that activities within their jurisdiction or control do not cause damage to the environment of other states or of areas beyond the limits of national jurisdiction. ${ }^{68}$

Although these principles are well established they are mere declarations or soft laws and therefore not binding. They are regarded by some as rules of customary law ${ }^{69}$ and if they are customary laws then they are binding on all States. These principles have been reaffirmed in Declarations adopted by the United Nations which include the Charter of Economic Rights and Duties of States, the World Charter for Nature, and the Declaration of the 2002 World Summit on Sustainable Development. ${ }^{70}$ The recognition of the principles by the ICJ as part of the corpus of international law relating to the environment may further affirm the customary nature of these principles. Furthermore, these principles ${ }^{71}$ contains two elements that cannot be divorced without fundamentally changing their sense and effect. These elements are (1) the sovereign right of states to exploit their own natural resources,

66 UNEP, Training Manual on International Environmental Law, Chapter 3 - Principles and Concepts of International Environmental Law, pp 23 - 37 at 27, https://www.wedocs.unep.or $\mathrm{g} /$ bitstream/hands/UNEP.pdf (Last accessed-20-august-2021).

67 Ibid.

68 Principle 2, Rio Declaration, 1992.

69 UNEP (n 66) 27.

70 Ibid. Principle 21 Stockholm and Principle 2 Rio are included in the United Nations Convention on the Law of the Sea (UNCLOS) as well as in article 20 of the Association of South East Asian Nations (ASEAN) Agreement on the Conversation of Nature and National Resources. The 1979 Convention on Long-range Trans-boundary Air pollution reproduces Principle 21 stating that it "expresses the common conviction that states have" on this matter. Principle 21 is contained in Article 3 of the 1992 Convention of Biological Diversity to which almost all states of the World are parties and as restated in the 1992 Rio Declaration, in the preamble of the 1992 UNFCCC, the 1999 Protocol on Water and Health to the Convention on the Protection and use of trans-boundary Water Courses and International Lakes and the 2001 Stockholm Convention on Persistent Organic Pollutants (POPs) Again the International Court of Justice (ICJ) recognized in an advisory opinion "the existence of the general obligation of states to ensure that activities within their jurisdiction and control respect the environment of other states or of areas beyond national control is now part of the corpus of international law relating to the environment". See The Legality of the Threat or Use of Nuclear Weapons, Advisory Opinion, ICJ Reports, (1996) 241 - 42.

71 Principle 21 Stockholm and Principle 2 Rio. 
and (2) the responsibility or obligation not to cause damage to the environment of other states. The interpretation is that states are responsible not only for their own activities but also with respect to all public and private activities within their jurisdiction or control that could harm the environment of other states or areas outside the limits of their jurisdiction. ${ }^{72}$ These Principles affirm the duty of States "to ensure" that activities within their jurisdiction or control do not cause damage to the environment of other States. The interpretation is that States are responsible not only for their own activities, but also with respect to all public and private activities within their jurisdiction or control that could harm the environment of other States or areas outside the limits of their jurisdiction. ${ }^{73}$

A major challenge of the Principles is that their exact scope have not been clearly determined. ${ }^{74}$ It seems that not all cases of trans-boundary damage resulting from activities within a States territory or control can be prevented or are unlawful. Although States may ask for compensation but the circumstances in which such outcomes will arise are not explicitly clear. ${ }^{75}$

\section{Convention on Biological Diversity, Rio de Janeiro 5 June 1992.}

This Convention is a global convention on the trans-boundary EIA provisions and initiatives. It entered into force on 29 December 1993 and Nigeria is a State party to it. Article 14 of the Convention provides that:

1. Each contracting Party, as far as possible and as appropriate, shall:

(c) Promote on the basis of reciprocity, notification exchange of information and consultation on activities under their jurisdiction or control which are likely to significantly affect adversely the biological diversity of other states or areas beyond the limits of national jurisdiction, by encouraging the conclusion of bilateral, regional or multilateral agreements as appropriate;

(d) In the case of imminent or grave danger or damage, originating under its jurisdiction or control, to biological diversity within the area under jurisdiction of other states or in areas beyond the limits of national jurisdiction notify immediately the potentially affected States of such danger or damage, as well as initiate action to prevent or minimize such danger or damage.

72 UNEP (n 66). It is an established practice that every state has the right to manage and utilize natural resources within its jurisdiction and to formulate and pursue its own environmental and developmental policies within the limits stipulated by international law. However, one limit imposed by international law on that right is that States have an obligation to protect their environment and prevent damage to neighbouring environments.

73 Areas beyond the limits of national jurisdiction would include the high seas, the air space above them, the deep sea bed, outer space, the moon and other celestial.

74 UNEP (n 66).

75 Ibid, 28. 
The Convention further encourages States to cooperate as appropriate with other States and International Organizations in developing educational and public awareness programmes, with respect to conservation and sustainable use of biological diversity. ${ }^{76}$

Trans-boundary impact assessment requires public education and awareness. All parties must cooperate in this regard and there must be exchange of information from all publicly available sources and such exchange must include exchange of results of technical, scientific and socio-economic research in addition to information on training and surveying programmes. Specialized knowledge, indigenous and traditional knowledge in combination with technologies referred to in Article 16 paragraph $1 .{ }^{77}$

\section{United Nations Convention on Law of the Sea 1982 (UNCLOS).}

UN Convention on Law of the Sea (UNCLOS) came into force on 16 November 1994. Nigeria is a state party to the Convention. Article 201 provides for monitoring of the risk or the effect of pollution and mandates States as far as possible, directly or through competent International Organisation to observe, evaluate and analyze by recognized scientific methods, the risk or effect of pollution of the marine environment. States are to publish the reports obtained pursuant to article 204 or provide such at appropriate intervals to the competent international organisation which, should make them available to all States. ${ }^{78}$ The UNCLOS further mandates States to take measures to prevent, reduce and control pollution of the marine environment when it is trans-boundary. ${ }^{79}$ States are to cooperate on a global or regional basis ${ }^{80}$ and when a State becomes aware that marine environment is in imminent danger or being damaged to immediately notify other States it seems likely to be affected by such damage, ${ }^{81}$ and contingency plans against pollution must be put in place in order to eliminate the effects of pollution and prevent or minimize the damage. ${ }^{82}$ UNCLOS further requires States to cooperate in studies and research programmes and exchanges of information and data. ${ }^{83}$

4. Convention on the Prevention of Marine Pollution by Dumping of Wastes and Other Matter (London Convention) 1992.

The Convention on the prevention of Marine Pollution by dumping of wastes and other matter was one of the first global conventions to protect the marine environment from

76 Article 13 (b) Convention on Biological Diversity 1992.

77 Article 17 (1) (2) Convention on Biological Diversity 1992.

78 Article 205 UNCLOS.

79 Article 194 UNCLOS.

80 Article 197 UNCLOS.

81 Article 198 UNCLOS.

82 Article 199 UNCLOS.

83 Article 200 UNCLOS. 
human activities and has been in force since 1975. The objective of the convention is to promote the effective control of all sources of marine pollution and take all practical steps to prevent pollution of the sea by dumping of wastes and other matter. ${ }^{84}$ In 1996, the London Protocol was agreed to further modernize the convention and, eventually, replace it. Under the Protocol, all dumping is prohibited, except for possibly acceptable wastes on the so-called 'reverse list'. ${ }^{85}$ The Protocol entered into force on March 24 2006. The objective of the London Convention and Protocol is to promote the effective control of all sources of marine pollution. State Parties shall take effective measures to prevent pollution of the marine environment caused by dumping at sea. ${ }^{86}$

The scope extends over "all marine water other than the internal waters". Article IV provides that the dumping of wastes or other matter listed in Annex I is prohibited. Wastes listed in annex II requires a prior special permit and the dumping of all other wastes or matter requires a prior general permit. ${ }^{87}$ The important innovation brought by the Protocol is the codification of the "precautionary approach" and the "polluter pays principle". The Protocol is an advanced international regulatory instrument addressing carbon capture and sequestration in sub-seabed geological formations and marine re-engineering. ${ }^{8}{ }^{8}$

\section{The Basel Convention on the Control of Trans-boundary Movement of Hazardous} Wastes and their Disposal 1989.

The Convention was adopted in Basel, Switzerland on March 22, 1989. It defines transboundary movement as: "any movement of hazardous wastes or other wastes from an area under the national jurisdiction of one state to or through an area under the national jurisdiction of another State or to or through an area not under the national jurisdiction of any State, provided at least two are involved in the movement". ${ }^{89}$ The Basel Convention includes hazardous wastes that are explosive, flammable, poisonous, corrosive, or toxic. ${ }^{90}$ The Convention requires the exporting State to give notice to importing States and its consent obtained before transporting the waste. Where such consent is obtained through fraud, misrepresentation or falsification or does not conform in a material way with the documents

84 IMODOCS, Convention on the Prevention of Marine Pollution by Dumping of Waste and Other Matter, 1972, https://www.docs.imo.org (accessed 12 September 2021).

85 Ibid.

86 Article I and II of the Convention and article 2 of the Protocol.

87 Article IV (a) (b) (c) London Convention 1972. Crude oil and its wastes refined petroleum products, petroleum distillate, residues and any mixture containing any of these, taken on board for the purposes of dumping, radioactive wastes or other radio-active matter are prohibited.

88 Hakeem (n59) 118.

89 Article 2 (3) Basel Convention 1989, Came into force in 1992.

90 Article 9(1) (a) - (e) Basel Convention 1989. 
or results in deliberate disposal (dumping) of hazardous waste it shall be deemed as illegal traffic. ${ }^{91}$

Where this is the case the exporter or the generator shall within 30 days take back the wastes and if it's not practicable the wastes should be disposed of in accordance with the provisions of the Convention. ${ }^{92}$

Article 1(3) and (4) of the Basel Convention exempts certain kinds of wastes from its regulatory scope. Art 1 (3) provides that the Convention does not regulate wastes that:"... as a result of being radioactive are subject to other international control system... applying specifically to radioactive materials..." In order to achieve its goal, the Convention provides for three key measures with binding obligation on parties. ${ }^{93}$

6. Bamako Convention on the Ban of Imports into Africa and the Control of Transboundary Movement and Management of Hazardous Wastes within Africa 1991.

The Bamako Convention is a regional instrument and was a direct response to the call on parities to enter into bilateral, multilateral and regional agreements on hazardous wastes ${ }^{94}$ to help achieve the objective of the Basel Convention. The Bamako Convention was adopted by African States to address certain aspects of hazardous wastes problem that the Basel Convention did not cover. ${ }^{95}$ The Bamako Convention entered into force in 1998 and its secretarial is with the African Union. The Bamako Convention regulate substances, especially pesticides, fertilizer and other chemicals that have been banned, canceled, denied registration by a government regulatory action or voluntarily withdrawn in the country of manufacture due to health and environment reasons. ${ }^{96}$ Radioactive wastes are included in the definition of hazardous wastes in the Convention. ${ }^{97}$ To strengthen the legal regime of the Convention, it obliges parties to take legal, administrative and other measures within their national jurisdiction to prohibit the import of all hazardous wastes into their territories. ${ }^{98}$

In order to prevent illegal dumping of waste, parties are to set up a "dump watch". Where wastes are dumped illegally, The Convention provides that such wastes be exported back to the country of origin. Article 9 allows for movement of wastes only upon receipt from the intended destination country of a written consent prior to export. Movement of

91 Annex III Basel Convention 1989.

92 Article 9(2) (3) (4) (5) Basel Convention 1989.

93 They include strict control of trans-boundary movement of hazardous wastes; environmentally sound management of hazardous wastes, and enforcement and implementation of the provisions of the convention at international and national levels.

94 Article II Basel Convention.

95 UNEP (n 66) 134

96 The Bamako Convention considers these as hazardous wastes.

97 Article 2 Bamako Convention.

98 Article 4, 6, 8 and 9 of the Bamako Convention. 
waste without such consent will be termed illegal traffic same will apply to movement pursuant to falsified consent, misrepresentation, fraud and those that result in deliberate disposal of wastes contrary to the provision of the convention. ${ }^{99}$

The Convention obliges each party to impose unlimited liability as well as joint and several liability on hazardous wastes generators. ${ }^{100}$ Parties also agreed to hold further consultation on matters relating to liability and compensation ${ }^{101}$ and come up with further joints regulations on the issues. Article 4 (3) further creates an obligation for environmentally sound management of hazardous wastes that are similar to the ones contained in the Basel Convention.

\section{Geneva Convention on the Continental Shelf and the High Seas (1958)}

Nigeria assented to this Treaty on May 28, 1991. It contains rules designed to prevent or minimize oil pollution arising from exploitation of the continental shell or its natural resources. It was used to mark the territory of the seas and its internal waters. ${ }^{102}$

8. The International Convention for the Prevention of Pollution of the Sea by Oil, 1954 (amended severally from 1958 through 1982 to 1992).

The International Convention for the Prevention of Pollution of the Sea by Oil was a result of deliberations of the inter-governmental maritime consultative organization (IMCO). Nigeria assented to the treaty on 22 April 1968. This treaty covers the obligation of states with regard to the pollution of the marine environment from all polluting sources such as oil, nuclear related activities etc. the treaty applies to all ships, except tankers under 150 tons gross tonnage and other ships under 500 tons gross tonnage. All ships covered by this treaty are to carry an oil record book in a form specified in the annex to be completed whenever certain operations take place. ${ }^{103}$

99 Article 8 allows parties to re-import any hazardous wastes exported to another party pursuant to agreements between persons in the countries concerned if the movement cannot be completed and the portion of hazardous waste already exported cannot be disposed of in the importing country in environmentally sounds manner. This is duty on States.

100 Article 4(3) Bamako Convention.

101 Article 12 Bamako Convention.

102 Hart Lawrence and Orupabo Sika, "Applicable International Environmental Impact Assessment Laws for the Niger Delta Area of Nigeria", African Journal of Environmental Science and Technology, (2016) Vol. 10, No 11, 386-393 at 390.

103 Ibid. 
9. Convention for Cooperation in the Petroleum and Development of the Marine and Coast Environment of West and Central Africa, 1984. ${ }^{104}$

Nigeria ratified this treaty on 5 August, 1984. The objectives of the treaty is to protect the marine environment of coastal zones and related internal waters which falls within the jurisdiction of the States of the West and Central African Region. ${ }^{105}$ Parties to the convention agreed to take all necessary measures to prevent, reduce, combat and control pollution ${ }^{106}$ of the convention area especially pollution from ships and air crafts, ${ }^{107}$ land based sources, ${ }^{108}$ and activities relating to exploration and exploitation of the sea bed, ${ }^{109}$ and pollution from or through the atmosphere. ${ }^{110}$ Parties also undertook to prevent, reduce, combat, and control coastal erosion, ${ }^{111}$ and protect and preserve rare or fragile ecosystem as well as the habitat of depleted, threatened or endangered species and other marine life in specially protected areas. ${ }^{112}$

State parties are to cooperate in dealing with pollution emergencies in the Convention area, ${ }^{113}$ and in exchanging data and other scientific information. ${ }^{114}$ Parties also undertook to develop technical and other guidelines regarding environmental impact assessment of their development projects ${ }^{115}$ and establish roles and procedures for the determination of liability and the payment of adequate and prompt compensation for pollution damage of the Convention area. ${ }^{116}$

10. The World Bank Operational Directive 4:00 of 1989 (Environmental Assessment).

This subsequently amended as Operational Directive 4.01 in $1991 .{ }^{117}$ It focuses on environmental impact assessment (EA) and it is designed to be a flexible process that makes environmental consideration an integral part of project preparation and allows environmen-

104 Convention for the Cooperation in the Protection and Development of the Marine and Coastal Environment of the West and Central African Region, https:/www.exolex.org/details/treaty/cove ntion-for-10-operation-in-the-protection-and-development-of-the-marine-and-coastal-environmen t-of-the-west-and-central-african-region-tre-000547/ (Last accessed 10 September 2021).

105 Ibid, objective.

106 Ibid, article 4.

107 Ibid, articles 5 and 6.

108 Ibid, article 7.

109 Ibid, article 8.

110 Ibid, article 9.

111 Ibid, article 10.

112 Ibid, article 11.

113 Ibid, article 12.

114 Ibid, article 13.

115 Ibid, article 14.

116 Ibid, article 15.

117 World Bank Guidelines on Environmental Assessment (EA) 1991. 
tal issues to be addressed in timely and cost effective manner during the preparation and implementation stages. The World Bank requires the execution of an EA on a proposed industrial activity by a borrower as precondition before granting any financial assistance in form of loans. ${ }^{118}$ The guideline raised critical areas such as biological diversity, coastal and marine resources management, cultural properties and hazardous and toxic materials and international waterways. ${ }^{119}$

\section{United Nations Framework Convention on Climate Change (1992) (UNFCCC)}

The aim of this Convention is to protect the climate system for present and future generations of humankind. ${ }^{120}$ To this and parities are to take precautionary measures to anticipate, prevent or minimize the causes of climate change and mitigate its adverse effects. ${ }^{121}$ States parities have a right to and should promote sustainable development policies and measures to protect the climate system against human-induced change which should be appropriate for the specific conditions of each party and should be integrated with national development programs noting that economic development is essential for adopting measure to address climate change. ${ }^{122}$

The ultimate objective of this convention is to stabilize greenhouse gas concentrations in the atmosphere at a level that would prevent dangerous anthropogenic interference with the climate system. ${ }^{123}$ The Convention, with 195 members enjoys a near universal membership. It is not a legally binding treaty, but provides opportunity for updates (Protocols) that can be used to set legally binding emission limits. ${ }^{124}$

\section{b. National Laws and Policies Preventing Trans-boundary Environmental Impacts}

Article 9 (5) of the Basel Convention mandate States to introduce appropriate national legislations to prevent and punish illegal traffic in hazardous wastes and other wastes. Article 4(4) also mandate States to take appropriate legal measures to implement and enforce the provisions of the Conventions. National legislation may be in form of laws, rules, regulations executive order and policies for the performance of the duties set out in the Convention. National laws strengthens compliance with international instruments. Nigeria has developed her own laws on the topic.

118 These Guideline are published in the banks EA sources book, Vols. 1-3 of 1991.

119 Ibid.

120 UNFCCC 1992, article 3(1).

121 Ibid, article 3(3).

122 Ibid, article 3(4).

123 Ibid, article 2.

124 UNFCCC - NAEI, UK-National atmosphere emissions inventory https:wwwnaei.beis.gov.uk/wh y-we-estimate?view=inventory (accessed 12 September, 2021). 


\section{i. The Harmful Wastes (Special Criminal Provisions) Act ${ }^{125}$}

Following the Koko incident of 1988, Nigeria enacted the Act with specific objective of prohibiting the carrying, depository and dumping of hazardous wastes on any land, territorial waters and matters relating thereto. The Act is essentially a penal legislation. Section 6 provides life imprisonment as punishment for offenders as well as the forfeiture of land or anything used to commit the offence. Section 12 defines the civil liability of any offender. The offender would be liable to persons who have suffered injury as a result of his offensive act. The jurisdiction of the Act is far reaching as it sought to remove any immunity conferred by diplomatic immunities and privileges on any person for the purposes of criminal prosecution. Despite the far reaching jurisdiction, it focuses mainly on criminal prosecution of damage and does not provide compensation to the victim of the damage. ${ }^{126}$

\section{ii. Environment Impact Assessment Act ${ }^{127}$}

The piece of legislation was enacted in 1992 as Decree No. 86 of 1992. The main goal of this piece of law is to ensure that possible negative impacts of development projects are predicted and addressed prior to the commencement of the project to ensure sustainable development. ${ }^{128}$ The Act provides for environment assessment referred to as environment audit. This process involves the writing of an environment audit report which complements the process of an environmental impact assessment and in some cases supplement it. ${ }^{129}$ Section 13 articulates cases where environmental assessment is required while section 14 notes the projects that are excluded from assessment. In 2018, a bill was laid before the National Assembly for the repeal of the Environmental Impact Assessment Act CAP E12, LFN 2004. ${ }^{130}$

The bill is made up of four parts and 73 sections. This bill is yet to be passed by the National Assembly. It is also important to note that the EIA Act did not make provision for trans-boundary environmental impacts. It is purely a local legislation dealing with environmental impacts of projects within Nigeria.

125 CAP H I, Laws of Federation of Nigeria (LFN) 2004.

126 Cecilia Chinwe Nwufo, "Legal Framework for the Regulation of Wastes in Nigeria", African Research Review, (2010) Vol. 4 No. 2, $491-501$ at 498.

127 CAP E12, LFN 2004.

128 Section I Environment Impact Assessment Act (hereafter EIA Act).

129 Section 7 EIA Act.

130 A Bill for an Act to Repeal the Environmental Impact Assessment Act, Cap. E12 Law of Federation of Nigeria 2004 and for Related Matters. 
iii. The National Environmental Standards and Regulations Enforcement Agency Act (NESREA) 2007

The Harmful Waste Special Criminal Provision Act does not have any provision regulating the trans-boundary movement of e-waste into Nigeria and this prompted the adoption of a specific regulation dealing with the importation of e-waste into Nigeria. ${ }^{131}$ NESREA is the agency saddled with the task of enforcing all environmental legislation in addition to checking and regulating e-waste trafficking, ${ }^{132}$ and it rose up to the task by adopting the EEE sector regulations. ${ }^{133}$ In addition to regulating the trans-boundary movement of e-waste, it functions as the major instrument through which Nigeria seeks to address environmental pollution arising from all operations and ancillary activities of the EEE sector in the country. ${ }^{134}$

The regulations are based on life-cycle approach and cover all aspects of the EEE sector from cradle to the grave. ${ }^{135}$ The regulations are hinged on the principles of reduce, repair, recover, recycle and re-use of EEE (5Rs) as the basic drivers of the sector. ${ }^{136}$ In line with the regulation, all new and used EEE imported into the country must be functional and all importers of EEE must register with NESREA. ${ }^{137}$ Again, all importers, manufacturers, distributors, retailers and assemblers of EEE product shall subscribe to an Extended Producer Responsibility Programmer (EPR), including the buy-back scheme, ${ }^{138}$ and the payment of an administrative change to promote environmentally sound management (ESM) of e-waste. ${ }^{139}$ It is important to note that the regulation prohibits the trans-boundary movement of e-waste that has end-of-life, unusable and unserviceable EEE into Nigeria. ${ }^{140}$ It is an offence punishable by a fine or imprisonment or both to undertake such activities. ${ }^{141}$ Any imported e-waste shall be sent back to the port of origin and vessel used in the importation

131 Emeka P Amechi and Babatude A. Oni, "Import of Electronic Waste into Nigeria: The Imperative of a Regulatory Policy Shift", Chinese Journal of Environmental Law, (2010), Vol. 3, 141 166.

132 The National Environmental Standards and Regulations Enforcement Agency (Establishment) Act No 25 of 2007 Section 7(a) and (h) (hereinafter NESRA Act).

133 National Environmental (Electrical / Electronics Sector) Regulations S.I No 23 of 2011, reg. 34 (2). (Hereinafter EEE Sector Regulations).

134 Ibid, Reg. 1(1).

135 Ibid, Reg. 1(2).

136 Ibid, Reg. 1(3).

137 Ibid, Reg. 2 and 3.

138 Ibid, Reg. 11(1).

139 Ibid, Reg. 11 (4) (d). This is applicable to importers of new and used EEE as part of EPR.

140 EEE Sector Regulation 34(2). See also Schedule 11, para 2(d) and (i) of the Regulations.

141 Ibid Reg. 61(1) (a), 67(1) and 67 (3) for the provisions prohibiting and criminalizing the importation of cathodes ray tubes. See Reg. 34(3), 61 (1) (c) and 67 (2). 
shall be forfeited to the Nigeria government. ${ }^{142}$ NESREA is also empowered to impose administrative punitive fines on the carrier of e-waste or used EEE mixed with e-waste. ${ }^{143}$

iv. National Oil Spill Detection and Response Agency (Establishment) Act, 2006 an Amended (NOSDRA).

The NOSDRA was enacted in 2006 and its objective is to monitor, regulate tiers one and two oil spills as well as coordinate, implement and review the National Oil Spill Contingency Plan for Nigeria ${ }^{144}$ by establishing a viable national operational Organisation that ensures a safe, timely, effective and appropriate response to all oil pollution as well as hazardous substances in the petroleum sector. ${ }^{145}$ The Agency shall ensure the co-ordination and implementation of the Plan within Nigeria ${ }^{146}$ including within 200 nautical miles from the baseline for which the breath of the territorial waters of Nigeria is measured; undertake surveillance, reporting, alerting and other response activities as the relate to oil spillages; encourage regional co-operation among member States of West African sub-region and in the Gulf of Guinea for combating oil spillage and pollution in our contiguous waters...strengthen the national capacity and regional action to prevent, control, combat and mitigate marine pollution. ${ }^{147}$

\section{Challenges in Implementing Legislations Preventing Trans-boundary Environmental Impact}

There are challenges militating against the implementation of the frameworks that prevent trans-boundary environmental impact. They include but not limited to:

1. Lack of substantive law on the subject both at the local and international level

Nigeria never had any legislation on environmental law prior to 1988 as already identified. It was in 1990 that the first substantive law came into existence shortly after it was repealed by the National Environmental Standard Regulation Enforcement Agency Act (NESREA) in 2007. This piece of legislation empowers the agency to implement the provisions of the Act with respect to regulating the Land, Air, Water and Noise pollution, ${ }^{148}$ while section 31 prescribes offences and penalties. There is also the Environmental Impact Assessment

142 EEE Sector regulations schedule 11, para 2 (f) and (g).

143 Ibid, para 2 (h).

144 NOSDRA, Section 5.

145 Ibid, section 5 (a).

146 Ibid, section7.

147 Ibid, section 7 (a) (b) (d).

148 National Environmental Standards and Regulations Enforcement Agency (Establishment) Act 2007 (NESREA), Section 20-29. 
Act ${ }^{149}$ which articulates the processes for an impact assessment of a project. This legislation provides for penalties and punishments ${ }^{150}$ but the penalties are not stringent enough to ensure compliance with rules. ${ }^{151}$ Therefore the law is honored more in breach. An individual is made to pay more than a firm or corporation. With all the mining activities that impact the environment especially in the Niger Delta region of the country, the multinationals are free to cause irreversible damages to the environment as the law lack teeth to hold them accountable. In 2018 a more robust legislation on EIA in Nigeria was presented to the National Assembly. ${ }^{152}$

This bill has laid at the National Assembly for three years and yet to be passed. The new bill is more robust and the punishment/offences ${ }^{153}$ provision is revised to meet current realities. Until it is passed, it cannot have any effect. Again, Nigeria is known to always ratify international instruments but fails woefully with implementation. By virtue of the provision of the 1999 Constitution ${ }^{154}$ as amended any treaty entered into by Nigeria that has not been re-legislated upon by the National Assembly will not have the force of law. This is a huge challenge as the absence of viable substantive domestic environmental law is disadvantageous to the country. The existing ones do not try to reform the decision making process they simply order administrators to act in a particular way.

2. Absence of Strong Substantive International Environmental Laws on the Subject of Environmental Protection.

Trans-boundary EIA regimes are not complemented by strong, substantive international law. There are so many treaties covering a wide range of environmental fields. Except for some, these agreements are marred by vague language and weak enforcement mechanisms. ${ }^{155}$ Few, like the Endangered Species Act contain strong mandates, but none empower tribunals to reverse government action because it is arbitrary. ${ }^{156}$ Potent environmental treaties have some challenges and they include: states' understanding of the damage inflicted on their neighbors, a tendency to discount the long term effects of pollution, developing nation's wariness of eco-imperialism, the technological difficulties of monitoring compli-

149 CAP E12, LFN 2004.

150 Ibid, section 60 .

151 Section 60 provides that: any person who fails to comply with the provision of this act shall be guilty of an offence under this Act and liable on conviction in the case of an individual to N100, 000 fine or to 5 years imprisonment and in the case of a firm or corporation to a fine of N50, 000 and not more than N100, 000 .

152 A Bill for an Act to repeal the Environmental Impact Assessment Act, CAP E12 LFN 2004, and for related matters.

153 Section 70, ibid.

154 Section 12, Constitution of the Federal Republic of Nigeria 999 as amended 2011.

155 Charles M. Kerstern, "Rethinking Trans-boundary Environmental Impact Assessment", The Yale Journal of International Law, (2009) Vol. 34, No. 173, 193.

156 Ibid, p 194. 
ance and the fact that most polluters are private non state actors. ${ }^{157}$ The above obstacles are in addition to the traditional covetousness with which States guard their sovereignty. States adopt procedural EIA regimes because they are unable to reach a consensus on substantive pollution restrictions for resources protected by functional environmental treaties, the American experience shows that trans-boundary EIA regimes will contribute significantly to a better environment but the problem is that so much of the world lacks these protections. ${ }^{158}$

It is observed that customary international law does not offer a better fortifying transboundary EIA regime. Some scholars ${ }^{159}$ have rallied around principle 21 of the Stockholm Declaration $^{160}$ as a crucial element of customary international environmental law. If the principle had been elevated to the status of binding customary law, it would indeed appear to be the perfect corollary to the trans-boundary assessment regime. A possible solution could be the extra territorial application of domestic environmental law but this has proven to be elusive. Many states are reluctant to apply their statutes outside their territory ${ }^{161}$ and maintain a presumption against the extraterritorial application that can only be rebutted by a clear showing of the intent of the legislature. ${ }^{162}$

Trans-boundary EIA treaties are necessary because State generally do not enforce their domestic environmental assessment laws outside the boundaries of their national jurisdiction. Finally Knox observed that "if the regional trans-boundary EIA agreements only require domestic EIA procedures to apply without discrimination to extra-territorial effects...then their effectiveness at preventing trans-boundary environmental harm would seem to depend on how effective domestic EIA is at preventing domestic environmental harm. ${ }^{163}$

157 Development in the Law- International Environmental Law, 104 Harvard L Rev 1484, 1550-51 (1991) as cited by Kerstern, C. ibid.

158 Thomas W. Merrill, 'Golden Rules for Trans-boundary Pollution,” Duke L. J (1997) Vol. 46, 931 at 970 .

159 Nicholas A Robinson, "International Trends in Environmental Assessment, BC ENVTL. AFF.L REV, (1992) 591 at 602. See John H Knox, "The Myth and Reality of Trans-boundary Environmental Impact Assessment, AM J. Int'l Law (2002), Vol. 96, 291.

160 Martha E. Candiello, "The Extra Territorial Reach of Environmental Law, TEMP.L. Rev (1997) 1235, 1236 (1991). Declining to apply the Resource Recovery and Conservation Act is a violation that occurred in the United Kingdom).

161 Paul Boudreaux, "Biodiversity and a New 'Best Case' for Applying the Environmental Statutes Extra-territorially, Environmental Law, (2007), 37.

162 Knox (n 159) 316.

163 Knox (n 159) 316. 


\section{Initiation of Legal Actions}

In Nigeria generally environmental right is not justiciable. Environmental provision in the law falls under the directive principle of state policy. ${ }^{164}$ No action can be instituted on grounds of environmental breach. Fortunately, the African Charter on Human and Peoples' Rights $^{165}$ now provides the platform for actions. In 2005 a Federal High Court in Nigeria in the Benin Judicial Division made Declaration against Shell Nigeria that the continuous flaring of gas was a breach of the right of the people of Iwverekhen Community to life. In 2021, a Federal High Court of Nigeria in celebrated case ordered shell to pay N45.9bn fine to Ogoni people for the environmental impact of their operations in Ogoni.

On the other hand trans-boundary EIA treaties do not include a cause of action for affected individuals who are not satisfied with the process. The only framework that includes an appeal for improper procedure are those implemented by development institutions, like the World Bank ${ }^{166}$ and they limit review to decisions concerning only projects financed by the bank. In most case if individuals want to challenges a State for not complying with the EIA procedures, they must look beyond the treaty itself. ${ }^{167}$

\section{Lack of Political Will}

Policy change alone does not give rise to effective implementation. Political and public support is very crucial. Nigeria has a plethora of laws, she has ratified or domestically enacted but the will to enforce these laws are lacking. The level of corruption is very over whelming that initiators of projects can afford to by pass all the procedures if they know the "right people". This has been the bane with implementation of laws. Political support for environmental policy is very important as it helps to set strategic direction, securing planning resources, championing environmental requirements with stakeholder and enforcing implementation. ${ }^{168}$

\section{Insufficient Resources and Capacity}

Environmental impact cannot be prevented if there are no strong institutions with sufficient resources and capacity to carry out the task. Nigeria is one country that has not done so well in building endurable institutions. In addition to lack of relevant institution, resources and capacity to drive the existing institutions are lacking. Government offices are starved

164 Chapter 11, CFRN 1999 as amended.

165 CAP A 9 LFN 2004, Articles 4, 16 and 24.

166 Int'l Bank for Reconstruction and Dev. (IBRD) and Int'l Dev. Association (IDA), World Bank Inspection Panel, Res No. IBRD 93-/0/IDA 93-6, 12 (Sept 22, 1993).

167 Kersten (n 155) p197.

168 WWF, "The Implementation Challenges: Taking Stock of Government Policies to Protect and Restore Environmental Flows", WWF Report 2021, 18. 
of funds. Workers are owed and the human resources keeps depleting because people are looking for greener pastures. Environmental issues and policies must be driven by relevant institution with capable hands. If there are no sustainable institutional framework the mechanisms and capacities required for successful implementation of the constituent elements of the framework can be a huge challenges. ${ }^{169}$

\section{Conflicts of Interest and Institutional Barriers}

One major challenge in Nigeria is the multiplicity of agencies and institutions saddled with almost the same responsibilities thereby creating a clash of interest. The institutions work at cross purposes. There's no synergy and cooperation neither is there any proof that they share information to strengthen their jobs. A lack of understanding of the interdependence of these various actors in the environmental field further exacerbates the institutional barriers between the various government agencies. Here, there is no strong cooperation between the political and academic institutions. This is a setback in developing the scientific and decision support tools needed to set and manage environment problems as they arise. ${ }^{170}$

\section{Cost of Trans-boundary EIA}

Most times the projects subject to trans-boundary EIA are usually very large and this increases the percentage cost. The extra cost needed for trans-boundary EIA may include: preparing and sending the notifications, preparing and broadcasting announcement; translation of documents into the language of the affected country; translation of comments and opinions received from the affected country; additional printing, distribution of documents, organization of public hearing, interpretation cost, travel and accommodation; fees charged by the competent authority in the affected country for the review of EIA documentation where applicable. ${ }^{171}$

\section{Problem of Identifying Points of Contact}

Working in a strange environment can be very challenging especially where the relevant persons to deal with are not known to those seeking them out. Who to contact for different types of activities in different sectors at different level of government is a huge challenge. This is even more difficult with States that operates decentralized government. ${ }^{172}$

169 Ibid, 19.

170 Ibid, 20.

171 Benefit and Cost of Trans-boundary EIA: Applying the UNECE Convention on Environmental Impact Assessment in a Trans-boundary Context, p3.

172 Wiek Schrage and Nick Bonvoisin, “Trans-boundary Impact Assessment: Frameworks, Experience and Challenge-Impact Assessment and Project Appraisal”, (2008) 26. 4, Pp 234-238 
9. Lack of Response from the affected Country

Where the affected country fails to respond to the notification, it makes it difficult to ascertain whether it does not wish to be consulted. The question would now be whether to continue sending information. ${ }^{173}$

10. Limited Public Access to Documents in the Internet

One of the challenges is the limited public access to documents that are online. Online sources of information is a particularly attractive mechanism in trans-boundary impact assessment but this will likely exclude the disadvantage groups.

11. Unwillingness of the Public to Participate with an Activity in another Country

Conducting cross-border EIA may not attract much public interest as it may not appear concrete (particularly with policies, plan and programmes) and may be too remote. ${ }^{174}$

12. A lack of equity, and whether equal opportunities to participate are sought for the public in the country of origin and in the affected country. ${ }^{175}$

13. Uncertainty about the timing of notifications.

At the latest, trans-boundary effects might be identified during preparation of the EIA or the strategic environmental assessment (SEA) document, but if identified earlier then informal notification would be best initiated earlier as well for example during scooping. Doing so is likely to reduce delays in arriving at the decision stage. ${ }^{176}$

14. Delays in implementing the activity

A trans-boundary consultation process may significantly lengthen the approval process because delays in notification, having to wait for a response from a potentially affected country, translation of documentation, additional consultation and public participation. ${ }^{177}$

DOI:103152/14615508x366004, https://www.ingentaconnect.com/content/beech/iapa (Last accessed 13 September 2021).

173 Ibid.

174 Ibid.

175 Ibid.

176 Ibid.

177 Ibid p 236. 
15. Incompatibility of National Systems for Impact Assessment and Public Participation.

This is also a challenge. For instance time allowed for different stages; public participation in scoping, which may lead to practical difficulties including delays and to problems of equity. ${ }^{178}$

16. Political trade-offs with national interest interfering with the trans-boundary impact assessment procedures. ${ }^{179}$

17. Disagreement about who covers the cost incurred by or in the affected country including the cost of public hearing and review of document by government. ${ }^{180}$ There's also limited access to public hearing especially where they are held in the country of origin. This is due to the cost of travel, border restrictions and the need for interpretation of the proceedings if held in a language foreign to the parties from the affected country.

\section{Benefits of Trans-boundary EIA ${ }^{181}$}

Trans-boundary EIA offers some benefit and these benefits are enhanced through the inclusion of stakeholders from affected countries by providing information and leading to changes in design. This also helps to promote and implement the frameworks on transboundary EIA. The benefit include:-

(a) Identification of the key environmental issues of a project and awareness of the environmental consequences of project implementation;

(b) Improvement of project design, and higher standard of mitigation;

(c) Protection of the environment, including the avoidance of environmentally sensitive areas through project re-siting or re-design;

(d) Identification of project alternatives (alternative location or technology) the mitigation and compensatory measures that reduce the environmental impact of the project. Information and suggestions may come from the public EIA experts, the developer and the stakeholders;

(e) Opportunities to consider climate change adaptations;

(f) Promotion of sustainable development in general;

(g) Promotion of good governance in the long-run, with public hearing providing important indirect benefits that can contribute to the capacity for democratic governance and an active civil society. ${ }^{182}$

178 Ibid.

179 Ibid.

180 Ibid.

181 Ibid, $\mathrm{p} 2$.

182 Almer, H. L and Koontz, T. M., 'Public Hearing for EIA in Post-Communist Bulgaria: Do they Work? Environmental Impact Assessment Review (2004), 473-493. 
(h) Provides a better framework for preparing conditions and legal agreements to govern future operation of the project. It provides better information and more objective decision making and public participation in government decision making is encouraged. ${ }^{183}$

\section{Recommendations}

Nigeria as noted earlier is an oil producing State and has had its fair share of environmental impact especially in the Niger Delta region of the country. The pollution in the area is likely to have affected the boundaries of neighbouring States. In 2012, there was massive flooding in Nigeria especially federating units that are close to the River Niger and also shares boundary with Cameroon as a result of the water dam project in Cameroon. This flooding sacked many communities in Nigeria the same may be happening to the land, water and air of other countries as a result of the exploration and exploitation of mineral resources in Nigeria.

Having examined the challenges to preventing trans-boundary environmental impact, the paper makes the following recommendations:

1. Nigeria should have a robust substantive legislation on environmental impact assessment. The current EIA Act has proven to be inadequate and should be reviewed. In this light, the EIA Act of 2018 that has been lying on the floor of the National Assembly should be passed. The new law must give policy direction and guideline and provide adequate framework for its implementation. There should be provision for trans-boundary environmental impact in the new law as it does not exist in the current framework.

2. Nigeria should implement the international treaties and protocols on trans-boundary environmental impact which she has ratified. The Harmful Waste Special Provisions Act should be reviewed and provisions applied when and where appropriate.

3. The courts must be ready and willing to entertain suits on environmental impact. Citizens of origin and affected countries must be involved in the trans-boundary impact assessment procedures. This will help mitigate the negative impact that may happen if the processes are not duly followed.

4. International communities must and should have a means of holding states accountable for trans-boundary environmental impacts. The TEIA regimes must be complemented by strong substantive international law.

5. Environmental rights in Nigeria should be made justiciable. This calls for the revision of the relevant sections of the Constitution. There must be sufficient political will to see this through. The corruption in the country must be tackled as it affects every strata of the economy and makes it impossible for necessary actions to be taken in the face of contraventions. The judiciary should brace up in the face of these challenges and make pronouncements in environmental litigations. 
6. Resources must deliberately be allocated to the Ministry of Environment in order to help develop the necessary capacity in this regard.

7. There's need to streamline the institutions that work in this sector. Multiplicity of institutions causes friction as roles overlap causing conflict. The existing institutions should synergize in the field of information sharing. This will help them to be more effective in tackling environmental concerns.

8. Most of the challenges articulated may be overcome by specifying either on a cases by case by case basis or in a formal agreement, various parameters including; the identification of contact points or a joint body; language considerations including translation arrangements, the allocation of costs criteria for determining the significance of effects, public participation arrangements and dispute settlement procedures.

\section{Conclusion}

This paper dealt with prevention of trans-boundary environmental impact, the legal framework and challenges of implementation. The paper examined EIA generally and then discussed trans-boundary EIA. This paper examined trans-boundary environmental impact in Nigeria and noted that prior to the Koko incident Nigeria had no substantive environmental legislation. The Koko incident was a wakeup call that led to the enactment of several environmental legal frameworks for domestic application and for trans-boundary effects. The paper also observed that trans-boundary EIA took root in Principle 21 of Stockholm and Principle 2 of Rio Declarations. The customary nature of these principles and others is still questionable as they have not been severally applied by the courts. The locus classicus on trans-boundary environmental impact, the Trial Smelter Arbitration has been a standalone judgment although, the International Court of Justice in its Advisory Opinion on the Legality of the Threat and Use of Nuclear Weapons referred to these principles, no international court have ruled on these.

This may either be because States are not willing to adjudicate on the trans-boundary impact of projects that affects their boundaries or alternative means are adopted in the resolution of disputes. Trails Smelter decision was reached over eight decades ago and courts should rise and implement this 'no harm rule' with respect to environmental litigations especially where it involves trans-boundary harm. Nothing stops domestic courts from using the principle too effective judicial application at the national level will invariably affect decisions at the international or regional courts. The paper articulated the benefits and challenges of preventing trans-boundary environmental impact in addition to the analysis of the existing legal frameworks. The paper made for reaching recommendations that would help prevent trans-boundary environmental impact. 


\section{Bibliography}

Abuja Platform on E-waste, a Communiqué issued by the International Conference on E-Waste Control, Abuja 20-21 July 2009.

Almer, H. L and Koontz, T. M., 'Public Hearing for EIA in Post-Communist Bulgaria: Do they Work? Environmental Impact Assessment Review (2004), 473-493.

Arbitral Trib: 3 UN Rep. Intl Arb. Awards 1938 (1941).

Atsegbua. L et al, Environmental Law in Nigeria: Theory and Practice (Ababa Press, 2004) 4-5.

Bamako Convention, Articles, 2, 4(3), 12, 4(3), 4, 6, 8 and 9.

Basel Convention 1989, Annex III, Articles 2 (3), 9(1) (a) - (e), 9(2) (3) (4) (5).

Bastmeijer, C. J., and Timo Koivurova, Theory and Practices of Trans-boundary Environmental Impact Assessment, Legal Aspects of Sustainable Development, Vol. 1 (Martinus, Nijhoff Publishers, 2008) 1, https://www.brill.com/view/htle.13066 (Last accessed 8th September, 2021).

Benefit and Cost of Trans-boundary EIA: Applying the UNECE Convention on Environmental Impact Assessment in a Trans-boundary Context, $\mathrm{p} 3$.

Benefits and Cost of Trans-boundary EIA: Applying the UNECE Convention on Environment Impact Assessment in a Trans-boundary Context", http://www.unece.org/eia/pamphlets.org (Last accessed 20 August 2021) 1-4.

Bidwell, A "UN Seeks to Solve Growing Global E-Waste Problem," US News and World Report (16 Dec. 2013), htts://www/usnews.com/news/articles/2013/12/16/un-seeks-to-solve-growing-global-e -waste-problems/ (Last accessed 4 September 2021).

Brown Weiss, E.,D. B Magraw and P.C. Szasz, International Environmental Law: Basic Instruments and References (Dobbs Ferry, NY; Transnational 1992).

Brownlie Ian, Principle of Public International Law, $5^{\text {th }}$ ed. (Clarendon Press: 1998) $435-6$.

Brownlie Ian, System of the Laws of Nations: State Responsibility Part I (Oxford University Press; 1983) 9.

Cecilia Chinwe Nwufo, "Legal Framework for the Regulation of Wastes in Nigeria", African Research Review, (2010) Vol. 4 No. 2, $491-501$ at 498.

Charles M. Kerstern, "Rethinking Trans-boundary Environmental Impact Assessment", The Yale Journal of International Law, (2009), Vol. 34, No. 173, 193.

Conference of the Parties to the Bamako Convention on the Ban of the Import into Africa and the Control of Trans-boundary Movement and Management of Hazardous Wastes within Africa, Second Meeting, Abidjan, Cote d' Ivoire, 30 January - 1 February 2018.

Constitution of the Federal Republic of Nigeria 999 as amended 2011, section 12.

Convention for the Cooperation in the Protection and Development of the Marine and Coastal Environment of the West and Central African Region, https://www.exolex.org/details/treaty/covention-for -10-operation-in-the-protection-and-development-of-the-marine-and-coastal-environment-of-the-w est-and-central-african-region-tre-000547/ (Last accessed 10 September 2021).

Convention on Biological Diversity 1992, Articles 13 (b), 17 (1) (2). 
Crew Fell Sick on Toxic Waste Ship, The Times (London, September 3, 1985), 1. See also "Dirty Jobs, Sweet Profits", US News and World Report, Nov. 21, 1988 at 155. See "Waste Dumpers Turning to West Africa", NY Times, July 17, 1988, 1 at 1, Column 2.

Decision 2/6 Prevention of electronic hazardous waste and the import and dumping of end -of-life waste electrical and electronic equipment in Africa $2018 \mathrm{UNEP} / \mathrm{BC} / \mathrm{co} / 2 / 6 /$.

Decision 6/14 of 19 May1978 of the Governing Council of UNEP, Official Records of the General Assembly, Thirty-Third Session, Supplement No 25 (A/33/25), and Annex 1.

Department of Environmental Affairs, "Minister Molewa Leads National Consultative Conference on Electronic and Electrical Waste (E-waste management in South Africa"; Press Media Release (4 $4^{\text {th }}$ September 2015) https://www.environment.gov.za/madiarelease/molewa-e-waste-conference/ (Last accessed $4^{\text {th }}$ September 2021).

Development in the Law- International Environmental Law, 104 Harvard L Rev 1484, 1550-51 (1991) as cited by Kerstern, $\mathrm{C}$.

Draft Articles on Prevention of Trans-boundary Harm from Hazardous Activities with commentaries, United Nations, 2008, 148.

East African Countries to Cooperate on e-waste management", Xinhua ( $25^{\text {th }}$ August 2016), https://ww w.kassfm.co.ke/new/index.php/business/item/1664-east-african-countries-to-coporate-on-e-waste -management, (Last accessed 7 September 2021).

Emeka P Amechi and Babatude A. Oni, "Import of Electronic Waste into Nigeria: The Imperative of a Regulatory Policy Shift”, Chinese Journal of Environmental Law, (2010), Vol. 3, 141 - 166.

Emeka P Amechi and Babatunde A Oni, "Import of Electronic Waste into Nigeria: The Imperative of a Regulatory Policy Shift", Chinese Journal of Environmental Law (2019), Vol.3, 141-146 at 141.

Environment Impact Assessment Act (hereafter EIA Act), CAP E 12 LFN, 2004.

Environmental Impact Assessment (EIA): An Introduction, 2015, Western Cape Government, Environmental Affairs Development Planning, South Africa.

Environmental Protection and Sustainable Development: Legal Principles and Recommendations, (Graham and Trotman/Mart Nijhoff, 1987) 75; adopted by the expert group. It was also noted that the duty not to cause substantial harm could be deduced from the non-treaty-based practices of states, and from the statements made by states individually and/or collectively.

Federal Environmental Protection Act 1988. This Act has been repealed by the National Environment Standards and Regulations Agency (Establishment) Act 2007.

Gozie, S. Ogbodo "Environmental protection in Nigeria: Two decades after the Koko Incident," Annual Survey of International \& Comparative Law (2009), Vol. 15, Issue 1, Article 2, 1 -18, http://www.digitalcommons.law.ggu.edu/ann/survey/vol15/iss1/2 (Last accessed 17 August 2021).

Hakeem O. Ijaiya, "Note on: Responsibility of Transnational Environmental Pollution under International Environmental Law”, Haramaya Law Review (2017), Vol. 6, 111 -124 at 113.

Hart Lawrence and Orupabo Sika, "Applicable International Environmental Impact Assessment Laws for the Niger Delta Area of Nigeria", African Journal of Environmental Science and Technology, (2016) Vol. 10, No 11, 386-393 at 390,

https://www.researchgate.net/publications/260244 (Last accessed 1th September 2021). 
Ikhariale, M, "The Koko Incident, the Environment and the Law"; In Shyllon, F (ed.), The Law and the Environment in Nigeria (Ibadan, Vintage Publishers 1989) 73 - 75.

IMODOCS, Convention on the Prevention of Marine Pollution by Dumping of Waste and Other Matter, 1972, https://www.docs.imo.org (Last accessed 12 September 2021).

Int'l Bank for Reconstruction and Dev. (IBRD) and Int'l Dev. Association (IDA), World Bank Inspection Panel, Res No. IBRD 93-/0/IDA 93-6, 12 (Sept 22, 1993).

Jin J., "E-Waste and the Regulatory Commons: A proposal for the Decentralization of International Environmental Regulation”, Brooklyn Journal of International Law (2014), Vol. 39, 1251 - 82 at $1256-8$.

John H. Knox, "The Myth and Reality of Trans-boundary Environmental Impact Assessment," American Journal of International Law, (2002), Vol. 96, Issue 2, 291 - 319.

Kutner, L, "The Control and Prevention of Transnational Pollution: A Case for World Habeas Ecologicus, U. Maimi Inter-Am L Review, (2015), Vol. 9, 257.

Lammers, J. G., Pollution of International Water Courses (The Hague, Martinus Nijhoff, 1984) 346 347 and $374-376$.

London Convention 1972, Article IV (a) (b) (c). Crude oil and its wastes refined petroleum products, petroleum distillate, residues and any mixture containing any of these, taken on board for the purposes of dumping, radioactive wastes or other radio-active matter are prohibited.

Martha E. Candiello, "The Extra Territorial Reach of Environmental Law, TEMP.L. Rev (1997) 1235, $1236(1991)$

Milka Dimitrovska "The Concept of International Responsibility of State in the International Public Law System”, Journal of Liberty and International Affairs (2015), Vol.1, No.2, 4.

Naomi Oreskes, "The Scientific Consensus on Climate Change", SCIENCE (2004), Vol. 306, No.5702, 1686 DOI: 10 1126/science.1103618.

National Environmental (Electrical / Electronics Sector) Regulations S.I No 23 of 2011, reg. 34 (2). (Hereinafter EEE Sector Regulations).

National Environmental Standards and Regulations Enforcement Agency (Establishment) Act 2007 (NESREA), Section 20-29.

Nicholas A Robinson, "International Trends in Environmental Assessment, BC ENVTL. AFF.L REV, (1992) 591 at 602. See John H Knox, "The Myth and Reality of Trans-boundary Environmental Impact Assessment, AM J. Int'l Law (2002), Vol. 96, 291.

Noah D Hall, “Trans-boundary Pollution: Harmonizing International and Domestic Law”, University of Michigan Journal of Law Reform (2007), Vol. 40, No.4, 681 - 746 at 681.

Ola C.S, Town and Country Planning and Environmental Laws in Nigeria, $2^{\text {nd }}$ ed. (Ibadan University Press 1984) petroleum refining regulation 1974 the oil pipeline Act 1956, the Factories Act.

Paul Boudreaux, "Biodiversity and a New 'Best Case' for Applying the Environmental Statutes Extra-territorially, Environmental Law, (2007), 37.

Principle 2, Rio Declaration, 1992. 
Principle 21 Stockholm and Principle 2 Rio are included in the United Nations Convention on the Law of the Sea (UNCLOS) as well as in article 20 of the Association of South East Asian Nations (ASEAN) Agreement on the Conversation of Nature and National Resources. The 1979 Convention on Long-range Trans-boundary Air pollution reproduces Principle 21 stating that it "expresses the common conviction that states have" on this matter. Principle 21 is contained in Article 3 of the 1992 Convention of Biological Diversity to which almost all states of the World are parties and as restated in the 1992 Rio Declaration, in the preamble of the 1992 UNFCCC, the 1999 Protocol on Water and Health to the Convention on the Protection and use of trans-boundary Water Courses and International Lakes and the 2001 Stockholm Convention on Persistent Organic Pollutants (POPs) Again the International Court of Justice (ICJ) recognized in an advisory opinion "the existence of the general obligation of states to ensure that activities within their jurisdiction and control respect the environment of other states or of areas beyond national control is now part of the corpus of international law relating to the environment". See The Legality of the Threat or Use of Nuclear Weapons, Advisory Opinion, ICJ Reports, (1996) 241 - 42.

Puckett and Smith, T, "Exporting Harm: the High Tech Trashing of Asia (Basel Action Network (BAN)), 2002) 4 - 10, https://www.ban.org/E-waste/techntrashfinalcomp.pdf (Last accessed 3rd September, 2021).

Sands, P., Principles of International Environmental Law Vol. 1: Frameworks, Standards and Implementation (Manchester University Press: 1975).

Secretariat of Basel Convention (SBC): Where are WECE in Africa? Findings from the Basel Convention E-Waste Africa Program (Dec 2011) 15 http://www/basel.int/portals/4/download.aspx?d= UNEP-CHW-E-waste-PUB-WeeAfricaReport.English.pdf (Last accessed $3^{\text {rd }}$ September 2021), and Ministry of Information and Communication Technology (ICT), Electronic Waste (E-waste) Management Policy for Uganda (2012), 10, https://www.ict.gov.ug/sites/default/files/resources/ele ctronic\%20waste\%20management\%20policy\%20for\%20uganda.pdf (Last accessed $3{ }^{\text {rd }}$ September 2021).

Section 245 -248 Nigeria Criminal Code.

Simpson J, “Africa Emerging as E-waste Dumping Ground", (Toxic Alerts, December, 2006) https://w ww/enews.toxicslink.org/news-view.php?id=3>(Last accessed 2 September 2021).

Sylvia F. Liu "The Koko Incident: Developing International Norms for the Trans-boundary Movement of Hazardous Waste", Journal of Natural Resources and Environmental Law (1992), Vol. 8 Issue 1, Article 9, 121 - 154, http://www.uknowlegde.uky.edu/jnrel/vol8/iss1/9, (accessed 17 August 2021).

The National Environmental Standards and Regulations Enforcement Agency (Establishment) Act No 25 of 2007 Section 7(a) and (h) (hereinafter NESRA Act).

The Stockholm Declaration - Report of the United Nations Con. on the Human Environment Stockholm, 5 - 16 June 1972, (United Nations Publication, Sales No. E. 73, 11. A. 14 and corrigendum), part one, chap 1.

Thomas W. Merrill, 'Golden Rules for Trans-boundary Pollution,” Duke L. J (1997) Vol. 46, 931 at 970. 
Timo Koivurova, Trans-boundary Environmental Impact Assessment in International Law, The Northern Institute for Environmental and Minority Law/University of Lapland, (Earthscan; 2011)1.

Toxics Links, E-Waste in India: System Failure Imminent-Take Action Now, (2004); https://www.toxic slink.org/docs/06040_repering.pdf (Last accessed 4 September, 2021).

Trail Smelter Case, 3 UN Rep. Intl Arb. Awards 1905 (1941).

UNEP, Environmental Law: Guidelines and Principles No. 2, Shared Natural Resources (Nairobi, 1978) 2. The Principles are reproduced in ILM, Vol. 17, No. 5 (September 1978) 1098.

UNEP, Training Manual on International Environmental Law, Chapter 3 - Principles and Concepts of International Environmental Law, 23 - 37 at 27, https://www.wedocs.unep.org/bitstream/hands/U NEP.pdf (Last accessed-20-august-2021).

UNFCCC - NAEI, UK-National Atmosphere Emissions Inventory https:wwwnaei.beis.gov.uk/why-we -estimate?view=inventory (accessed 12 September, 2021).

United Nations Convention on the Law of the Sea (UNCLOS), Articles 194, 197,198, 199, 200, 205.

Wiek Schrage and Nick Bonvoisin, "Trans-boundary Impact Assessment: Frameworks, Experience and Challenge-Impact Assessment and Project Appraisal", (2008) 26. 4, Pp 234-238 DOI: 103152/14615508x366004, https://www.ingentaconnect.com/content/beech/iapa (Last accessed 13 September 2021).

World Bank Guidelines on Environmental Assessment (EA) 1991.

WWF, "The Implementation Challenges: Taking Stock of Government Policies to Protect and Restore Environmental Flows", WWF Report 2021, 18. 